\title{
Maxillary Sinus Cancer pNX TNM Finding v6 and v7
}

National Cancer Institute

\section{Source}

National Cancer Institute. Maxillary Sinus Cancer pNX TNM Finding v6 and v7. NCI

Thesaurus. Code C65031.

Maxillary sinus cancer in which the regional lymph nodes cannot be assessed. (from AJCC 6th and 7th Eds.) 